Archives of Agriculture and Environmental Science

\title{
Effects of different fertilizers on the growth and yield of okra (Abelmoschus esculentus L.) in summer season in Chitwan, Nepal
}

\author{
Sandesh Bhandari ${ }^{*}{ }^{*}$ D , Subodh Raj Pandey ${ }^{1}$, Kushal Giri ${ }^{1}$, Pratiksha Wagle ${ }^{1}$, Suman Bhattarai ${ }^{1}$ \\ and Ram Babu Neupane ${ }^{2}$
}

${ }^{1}$ Undergraduate student, Agriculture and Forestry University, Rampur, Chitwan, NEPAL
${ }^{2}$ Horticulture Farm Manager, Agriculture and Forestry University, NEPAL
${ }^{*}$ Corresponding author's E-mail: bhandarisandesh2000@gmail.com

\section{ARTICLE HISTORY}

Received: 05 October 2019

Revised received: 31 October 2019

Accepted: 16 November 2019

\section{Keywords}

Benefit-cost ratio

Fertilizers

Income

Okra

Organic matter

Poultry

Yield

\begin{abstract}
An experiment was conducted in the Horticulture Farm of Agriculture and Forestry University to demonstrate the effects of different fertilizers on the yield and yield parameters of okra (var. Arka Anamika). The experiment was laid out in Randomized Complete Block Design (RCBD) consisting of seven treatments and three replications. The various treatments used in the experiment were goat manure, sesame cake, mustard cake, synthetic fertilizer (NPK), poultry manure, vermicompost and untreated control. The required dose of nitrogen was fulfilled by the fertilizer itself whereas insufficient amount of phosphorous and potassium was fulfilled by addition of single super phosphate and muriate of potash respectively. The fertilizers were applied on the basis of recommendation given by the Nepal Agriculture Research Council (NARC). The effect of poultry manure on number of open flowers and number of fruits at 40 DAS was found superior. The effect of poultry manure on plant height, number of leaves, plant diameter was found superior at 50 DAS. Goat manure produced the superior result on number of open flowers at 50 DAS. Poultry manure on the number of leaves and plant height produced the significant result at 60 DAS. Synthetic fertilizer responded well to number of fruits at 60 DAS. Sesame cake produced the superior results at 70 DAS on number of buds. Poultry manure responded well to all the parameters and produced the yield of 200 qt./ha with the $\mathrm{BC}$ ratio of 1.77 . This experiment suggests the farmers to use the poultry manure to get the highest economic return. Vermicompost and mustard cake producing the superior and significant yield in this research are not recommended as they have low $\mathrm{BC}$ ratio unless effective measures are encouraged to reduce the cost of this fertilizers.
\end{abstract}

Citation of this article: Bhandari, S., Pandey, S.R., Giri, K., Wagle, P., Bhattarai, S. and Neupane, R.B. (2019). Effects of different fertilizers on the growth and yield of okra (Abelmoschus esculentus L.) in summer season in Chitwan, Nepal. Archives of Agriculture and Environmental Science, 4(4): 396-403, https://dx.doi.org/10.26832/24566632.2019.040405

\section{INTRODUCTION}

Okra (Abelmoschus esculentus) is an important summer vegetable of Nepal which belongs to family Malvaceae (Maurya et al., 2013). It was originated from Africa and spread to tropics, subtropics and warmer part of temperate region. Okra is the rich source of carbohydrate, amino acids, vitamin which have multipurpose use like fresh or cooked consumption, as fodder to animal, medicinal and industrial use (Farinde et al., 2007; Kumar et al., 2017). Okra response very well to fertilizer application and an effective fertilizer use is the key to its higher growth and yield (Buob, 2008; Kumar, 2019).

Mineral fertilizers only assure the rapid and short-term growth and yield improvement (Ware and Collum, 1980) but become unable to ensure sustainability of agricultural production (Titiloye et al., 1985). The application of organic manure could ameliorate the acidic condition of soil to improve crop production (Akande et al., 2003). Poultry manure in comparison to 
other supplies more nutrient to plant (Garg and Bahl, 2008). In addition to releasing nutrients, poultry manure is rich in organic matter which improves the physical properties of soil (Ayeni, 2011). Poultry manure increases plant height (Aniefiok, 2013). Earthworm manures is known to restore the destructive effect of chemical fertilizers and improve soil properties and facilitates the growth of the crops (Sinha, 2009). Continuous use of vermicompost reclaims the soil and rejuvenates it. The growth, number of pods and yield of okra increased with increasing amount of goat manure (Awodun, 2007). Various plant originated manures like mustard oil cakes, sesame oil cakes, peanut cakes, castor cakes helps in plant growth and increase yield by reducing the incidence of phytonematodes (Frederick, 2015; Sumbul, 2015). In this investigation, the effect of different organic and inorganic fertilizers on the growth and yield of okra were studied.

\section{MATERIALS AND METHODS}

\section{Experimental site}

It was carried out in the horticulture farm of Agriculture and Forestry University. The latitude and longitude of the research site is $27^{\circ} 37^{\prime}$ and $84^{\circ} 37^{\prime}$, respectively. The experiment was conducted from April 7, 2018 to July 2, 2018 and took 85 days from sowing to economic harvesting. It is located at an altitude of 250 meters above sea level. The soil status of the experimental site during field preparation was obtained by soil analysis report from Agriculture Technology Center, Lalitpur, Nepal (Table 1).

\section{Experimental design}

This experiment was carried out in Randomized Control Block Design (RCBD). It consists of 7 treatments and is replicated 3 times. The spacing of $50 \mathrm{~cm} \times 30 \mathrm{~cm}$ and wide spacing of $1 \mathrm{~m}$ around the research plot was used. Spacing of $75 \mathrm{~cm}$ was used to separate the treatments and replications. The area of the plot is $2.5 \mathrm{~m} \times 1.8 \mathrm{~m}$ and thus covering $4.5 \mathrm{~m}^{2}$. The research filed covers the entire area of $210.1 \mathrm{~m}^{2}$.

Table 4. Effect of different fertilizers on performance of okra at 10 DAS.

\begin{tabular}{lcc}
\hline \multirow{2}{*}{ Treatments } & \multicolumn{2}{c}{ 10 DAS } \\
\cline { 2 - 3 } & Plant height (cm) & Number of leaves \\
\hline Vermicompost & 6.733333 & 3.066667 \\
Sesame cake & 6.800000 & 3.000000 \\
Synthetic fertilizer & 6.400000 & 3.000000 \\
Goat manure & 7.300000 & 2.933333 \\
Mustard cake & 6.333333 & 2.933333 \\
Poultry manure & 6.600000 & 2.933333 \\
Control & 6.433333 & 2.866667 \\
SEM( \pm ) & 0.15 & 0.02 \\
LSD (0.05) & 1.05 & 0.168 \\
CV (\%) & 8.86 & 3.18 \\
F-test & $\mathrm{NS}$ & $\mathrm{NS}$ \\
\hline
\end{tabular}

Note: Means with the same letter are non-significant at $p=0.05$ by DMRT, SEM: Standard error of mean, LSD: Least significant difference, $\mathrm{CV}$ : Coefficient of variation, NS: Non-significant.
Table 1. Description of soil status of the research field.

\begin{tabular}{ll}
\hline Description & Properties \\
\hline Soil texture & Sandy Loam \\
Organic matter percentage & 3.5 \\
Soil pH & 5.54 \\
Electrical conductivity $(\mathrm{mmho} / \mathrm{cm})$ at $25 @$ & 0.13 \\
Nitrogen percentage & 0.17 \\
$\mathrm{P}_{2} \mathrm{O}_{5}(\mathrm{Kg} / \mathrm{ha})$ & 55.09 \\
$\mathrm{~K}$ & $\mathrm{O}(\mathrm{Kg} / \mathrm{ha})$ \\
Sand percentage & 342.58 \\
Silt percentage & 76.4 \\
Clay percentage & 18.67 \\
\hline
\end{tabular}

Brassica oleracea var. botrytis was grown last season in this research field. Arka Anamika is resistant to yellow vein mosaic virus.

Table 2. NPK content of different fertilizers.

\begin{tabular}{llll}
\hline Manures & N\% & P\% & K\% \\
\hline Goat manure & 3 & 1 & 2 \\
Sesame cake & 6.61 & 2.1 & 1.1 \\
Mustard cake & 4.52 & 1.78 & 1.4 \\
Poultry manure & 1.2 & 0.45 & 0.8 \\
Vermicompost & 2.35 & 1.6 & 1.5 \\
\hline
\end{tabular}

Table 3. Amount of different fertilizer added in the research field.

\begin{tabular}{llll}
\hline Manures & $\begin{array}{l}\text { Applied manures } \\
\text { (for N) kg }\end{array}$ & SSP (g) & MOP (g) \\
\hline Goat manure & 3.000 & 318.75 & - \\
Sesame cake & 1.361 & 327.56 & 20.03 \\
Mustard cake & 1.991 & 284.75 & - \\
Poultry manure & 7.500 & 295.31 & - \\
Vermicompost & 3.829 & 123.25 & - \\
Synthetic & 126.74 & 176.08 & 45 \\
fertilizer (NPK) & g Urea & gDAP & \\
Control & - & - & - \\
\hline
\end{tabular}

Treatment and trial management

There are seven different treatments used in the experiment. They are: T1: Goat manure, T2: Sesame cake, T3: Mustard cake, T4: Synthetic fertilizers (NPK), T5: Poultry manure, T6: Control and T7: Vermicompost. The field was prepared 5 days before sowing and seed was sown after soaking for $24 \mathrm{hrs}$. Required dose of fertilizer application was given by Nepal Agriculture Research Council (NARC) i.e. 200:180:60 kg NPK/ha which accounts 90:81:27 g NPK/ $4.5 \mathrm{~m}^{2}$. The NPK content different fertilizer determined by animal science laboratory of AFU is given in Table 2.

The manures were applied to fulfill the required dose of nitrogen. Insufficient dose of phosphorous and potassium were applied through single super phosphate (SSP) and muriate of potash (MOP) respectively. The applied manures per plot are given in the Table 3.

\section{Data collection}

There were altogether 30 plants in each plot. There were 18 border plants and 12 inner plants. Out of the 12 inner plants, 5 plants were sampled by using randomizer application and the data were collected on the following parameters. 
Estimation of vegetative parameters

Plant height: The plant height was measured in 10DAS, 20DAS, 30DAS, 40DAS, 50DAS and 60 DAS. It was measured using the measuring tape from the base to the tip of the plant.

Plant diameter: The data for the plant diameter was measured in 20DAS, 30DAS, 40DAS, 50DAS and 60DAS. The plant diameter was measured just below the $1^{\text {st }}$ node from the ground.

Number of leaves: The number of fully leaves was measured in 10DAS, 20DAS, 30DAS, 40DAS, 50DAS and 60 DAS.

\section{Reproductive parameters}

Number of pods: The total number of pods was counted in 40DAS, 50DAS, 60 DAS and 70 DAS.

Number of fruits: The total number of fruits was counted in 40DAS, 50DAS, 60DAS and 70 DAS

Number of flowers: The total number of fully opened flowers was counted in 40DAS, 50DAS, 60DAS and 70 DAS.

Yield: Okra fruits were collected in every 3 days by multiple harvesting from 45 DAS and they were picked 20 times up to economic production level.

\section{Statistical analysis}

The data were collected and recorded in MS-Excel (Office Package 2007) and subjected to statistical analysis according to one-way ANOVA using R-stat (version: 3.4.2).

\section{Economic analysis}

$\mathrm{BC}$ ratio of various treatments was calculated. The cost of various materials involved in the research was: Goat manure: NRs 5/kg, Sesame cake: NRs 25/kg, Mustard cake: NRs 30/kg,
Poultry manure: NRs 5/kg, Vermicompost: NRs 18/kg, Urea: NRs 20/kg, DAP: NRs 45/kg, SSP: NRs 18/kg, Okra seed: NRs 3500/kg, MOP: NRs 60/kg, Labour: NRs 600/day, NRs 30/kg of the produce. It was calculated by adding all the cost except fertilizers to obtain the common cost (Table 12). The common cost was added to the cost of manures to obtain the total cost (Table 13). The yield was multiplied by the average value of the produce to obtain the benefit (Table 14). Thus BC (Table 14) ratio was calculated.

Meteorological data during the investigation from April 7 to July 2

National Maize Research Program (NMRP) under Nepal Agriculture Research Council (250 m far from the research site) provided required meteorological data of the entire cropping period. The maximum temperature ranges from $27.2{ }^{\circ} \mathrm{C}$ to $38.01^{\circ} \mathrm{C}$ and the minimum temperature ranges from $27.02^{\circ} \mathrm{C}$ to $29.8^{\circ} \mathrm{C}$. The research field received $385 \mathrm{~mm}$ rainfall during the entire cropping period (Figure 1).

\section{RESULTS AND DISCUSSION}

The effect of plant height and number of leaves at 10 DAS was found non-significant (Table 4). Similarly, the effect of plant height, number of leaves and plant diameter at 20 DAS was found non-significant (Table 5). Same result continues with the okra plant at 30 DAS (Table 6).

In 40 DAS, the effect of plant height, number of leaves, plant diameter and number of buds was found non-significant. But, the data for the number of open flowers and number of fruits was found significant at $1 \%$ and $5 \%$ level of significance respectively (Table 7). Poultry manure and vermicompost was found superior in case of number of buds whereas poultry manure, goat manure, vermicompost and mustard cake were found superior in case of number of fruits. The result corresponds with the findings of (Ajari et al., 2003) in which Poultry manure was found superior in comparisons to other organic manure.



Figure 1. Meteorological data during the investigation from April 7 to July 2. 
Table 5. Effect of different fertilizers on performance of okra at 20 DAS.

\begin{tabular}{lccc}
\hline \multirow{2}{*}{ Treatments } & & 20 DAS & Plant diameter (cm) \\
\cline { 2 - 4 } Goat manure & Plant height $(\mathrm{cm})$ & Number of leaves & 0.5400000 \\
Sesame cake & 7.300000 & 5.466667 & 0.5500000 \\
Vermicompost & 6.800000 & 5.266667 & 0.5133333 \\
Poultry manure & 6.733333 & 5.600000 & 0.5666667 \\
Synthetic fertilizers & 6.600000 & 5.866667 & 0.6133333 \\
Mustard cake & 6.400000 & 5.600000 & 0.5866667 \\
Control & 6.333333 & 5.400000 & 0.5466667 \\
SEM( \pm ) & 6.300000 & 5.633333 & 0.01 \\
LSD (0.05) & 0.15 & 0.1 & 0.893 \\
CV $(\%)$ & 0.801 & 0.911 & 8.97 \\
F-test & 6.78 & 9.23 & $\mathrm{NS}$ \\
\hline
\end{tabular}

Note: Means with the same letter are non-significant at $\mathrm{p}=0.05$ by DMRT, SEM: Standard error of mean, LSD: Least significant difference, CV: Coefficient of variation, NS: Non-significant.

Table 6. Effects of different fertilizers on performance of okra at 30 DAS.

\begin{tabular}{lccc}
\hline \multirow{2}{*}{ Treatments } & \multicolumn{3}{c}{ 30 DAS } \\
\cline { 2 - 4 } & Plant height & Number of leaves & Plant diameter \\
\hline Mustard cake & 26.93333 & 7.466667 & 0.7266667 \\
Synthetic fertilizers & 26.93333 & 8.333333 & 0.7066667 \\
Poultry manure & 24.90000 & 8.666667 & 0.7000000 \\
Sesame cake & 26.13333 & 7.400000 & 0.6800000 \\
Goat manure & 26.26667 & 8.466667 & 0.6133333 \\
Vermicompost & 25.13333 & 8.666667 & 0.6066667 \\
Control & 23.46667 & 7.600000 & 0.5933333 \\
SEM( \pm ) & 0.44 & 0.2 & 0.02 \\
LSD (0.05) & 3.26 & 1.57 & 0.128 \\
CV $(\%)$ & 7.15 & 10.9 & 10.9 \\
F-test & NS & NS & NS \\
\hline
\end{tabular}

Note: Means with the same letter are non-significant at $p=0.05$ by DMRT, SEM: Standard error of mean, LSD: Least significant difference, CV: Coefficient of variation, NS: Non-significant.

Table 7. Effects of different fertilizers on performance of okra at 40 DAS.

\begin{tabular}{lcccccc}
\hline & \multicolumn{5}{c}{ 40 DAS } \\
\cline { 2 - 6 } Treatments & Plant height & $\begin{array}{c}\text { Number of } \\
\text { leaves }\end{array}$ & Plant diameter & $\begin{array}{c}\text { Number of } \\
\text { buds }\end{array}$ & $\begin{array}{c}\text { Number of } \\
\text { open flowers }\end{array}$ & $\begin{array}{c}\text { Number of } \\
\text { fruits }\end{array}$ \\
\hline Vermicompost & 53.66667 & 17.46667 & 1.19333 & 5.066667 & $0.3666667^{\mathrm{a}}$ & $0.8666667^{\mathrm{a}}$ \\
Poultry manure & 59.20000 & 17.13333 & 1.27333 & 5.866667 & $0.6333333^{\mathrm{a}}$ & $0.9666667^{\mathrm{a}}$ \\
Mustard cake & 55.33333 & 15.53333 & 1.26667 & 5.066667 & $0.3666667^{\mathrm{b}}$ & $0.9333333^{\mathrm{a}}$ \\
Synthetic fertilizers & 60.86667 & 15.00000 & 1.28000 & 6.466667 & $0.3000000^{\mathrm{b}}$ & $0.6000000^{\mathrm{ab}}$ \\
Sesame cake & 61.40000 & 14.80000 & 1.28000 & 5.133333 & $0.3666667^{\mathrm{b}}$ & $0.6666667^{\mathrm{ab}}$ \\
Goat manure & 60.20000 & 14.20000 & 1.24000 & 4.466667 & $0.3000000^{\mathrm{b}}$ & $0.9333333^{\mathrm{a}}$ \\
Control & 51.76667 & 14.00000 & 1.20333 & 5.033333 & $0.2666667^{\mathrm{b}}$ & $0.4000000^{\mathrm{b}}$ \\
SEM( \pm ( ) & 1.17 & 0.72 & 0.03 & 0.24 & 0.03 & 0.06 \\
LSD (0.05) & 8.96 & 5.47 & 0.21 & 2.07 & 0.154 & 0.38 \\
CV (\%) & 8.76 & 19.9 & 9.44 & 21.9 & 23.4 & 27.8 \\
F-test & NS & NS & NS & NS & $* *$ \\
\hline
\end{tabular}

Note: Means with the same letter are non-significant at $p=0.05$ by DMRT, SEM: Standard error of mean, LSD: Least significant difference, CV: Coefficient of variation, NS: Non-significant, ${ }^{*}: 5 \%$ level of significance, $1 \%$ level of significance. 
In 50 DAS, the vegetative parameters such as plant height, number of leaves and plant diameter was found significant at $5 \%$ probability level. The reproductive parameters such as number of buds and number of open flowers were found non-significant. The data for the number of fruits was found significant at $5 \%$ probability level (Table 8). In all the cases poultry manure was found superior except in the number of buds, where goat manure was found superior. In 60 DAS, the effect on plant height was found nonsignificant. Whereas, the data for the number of leaves and plant diameter was found significant at $5 \%$ and $1 \%$ probability level respectively. In both the cases, poultry manure was found superi- or. The effect on number of fruits was found significant at $5 \%$ probability level (Table 9). Synthetic fertilizer was found superior followed by poultry manure, vermicompost, sesame cake, goat manure, mustard cake and control. The effect on the number of fruits was found non-significant (Table 9). In 70 DAS, the effect on number of buds was found statically significant at $5 \%$ probability level. Sesame cake produced the superior number of buds followed by poultry manure, synthetic fertilizers, goat manure, mustard cake, vermicompost and untreated control. The effect on number of open flowers and number of fruits was found non-significant (Table 10).

Table 8. Effects of different fertilizers in performance of okra at 50 DAS.

\begin{tabular}{|c|c|c|c|c|c|c|}
\hline \multirow[b]{2}{*}{ Treatments } & \multicolumn{6}{|c|}{ 50 DAS } \\
\hline & Plant height & $\begin{array}{c}\text { Number of } \\
\text { leaves }\end{array}$ & Plant diameter & $\begin{array}{c}\text { Number of } \\
\text { buds }\end{array}$ & $\begin{array}{c}\text { Number of } \\
\text { open flowers }\end{array}$ & $\begin{array}{c}\text { Number of } \\
\text { fruits }\end{array}$ \\
\hline Poultry manure & $88.73333^{a}$ & $26.73333^{a}$ & $1.960000^{\mathrm{a}}$ & 5.666667 & $0.6666667^{a b}$ & 2.066667 \\
\hline Vermicompost & $87.13333^{\mathrm{a}}$ & $24.93333^{a}$ & $1.833333^{\mathrm{ab}}$ & 6.800000 & $0.6666667^{a b}$ & 1.400000 \\
\hline Sesame cake & $84.20000^{\mathrm{abc}}$ & $19.73333^{b c}$ & $1.746667^{\mathrm{abc}}$ & 8.200000 & $0.3333333^{c}$ & 1.333333 \\
\hline Goat manure & $54.66676^{\mathrm{ab}}$ & $22.06667^{a b c}$ & $1.586667^{\mathrm{abc}}$ & 6.933333 & $0.8000000^{a}$ & 1.466667 \\
\hline Mustard cake & $77.46667^{\mathrm{bcd}}$ & $18.80000^{c}$ & $1.500000^{\mathrm{bc}}$ & 6.600000 & $0.4666667^{\mathrm{bc}}$ & 1.733333 \\
\hline Synthetic fertilizers & $75.20000^{\mathrm{cd}}$ & $17.93333^{c}$ & $1.343333^{c}$ & 8.666667 & $0.4666667^{b c}$ & 1.666667 \\
\hline Control & $72.36667^{d}$ & $17.00000^{c}$ & $1.336667^{c}$ & 6.466667 & $0.3333333^{c}$ & 1.466667 \\
\hline $\operatorname{SEM}( \pm)$ & 1.65 & 0.93 & 0.07 & 0.33 & 0.05 & 0.11 \\
\hline LSD (0.05) & 9.11 & 5.3 & 0.401 & 2.16 & 0.261 & 0.74 \\
\hline CV (\%) & 6.29 & 14.2 & 14 & 16.2 & 27.5 & 26.2 \\
\hline F-test & $*$ & $*$ & * & NS & $*$ & NS \\
\hline
\end{tabular}

Note: Means with the same letter are non-significant at $p=0.05$ by DMRT, SEM: Standard error of mean, LSD: Least significant difference, CV: Coefficient of variation, NS: Non-significant, ${ }^{*}: 5 \%$ level of significance.

Table 9. Effects of different fertilizers on performances of okra at 60 DAS.

\begin{tabular}{|c|c|c|c|c|c|c|}
\hline \multirow[b]{2}{*}{ Treatments } & \multicolumn{6}{|c|}{ 60 DAS } \\
\hline & Plant height & $\begin{array}{c}\text { Number of } \\
\text { leaves }\end{array}$ & Plant diameter & $\begin{array}{c}\text { Number of } \\
\text { buds }\end{array}$ & $\begin{array}{l}\text { Number of } \\
\text { open flowers }\end{array}$ & $\begin{array}{c}\text { Number of } \\
\text { fruits }\end{array}$ \\
\hline Poultry manure & 118.6000 & $44.60000^{a}$ & $2.200000^{a}$ & 10.566667 & 0.8 & $3.666667 a b$ \\
\hline Sesame cake & 117.7333 & $35.66667^{\mathrm{ab}}$ & $1.773333^{\mathrm{bc}}$ & 9.8000000 & 0.8 & $3.100000 a b c$ \\
\hline Vermicompost & 111.6667 & $31.73333^{b}$ & $1.846667^{b}$ & 8.833333 & 0.9 & 3.100000abc \\
\hline Synthetic fertilizers & 111.2000 & $30.73333^{b}$ & $1.676667^{\mathrm{bc}}$ & 9.200000 & 0.6 & $4.100000 a$ \\
\hline Goat manure & 109.3333 & $34.86667^{\mathrm{ab}}$ & $1.936667^{\mathrm{ab}}$ & 10.100000 & 0.6 & $2.900000 b c$ \\
\hline Mustard cake & 107.1333 & $29.60000^{b}$ & $1.740000^{b c}$ & 9.400000 & 0.5 & $2.400000 c$ \\
\hline Control & 103.6667 & $25.06667^{b}$ & $1.436667^{c}$ & 8.933333 & 0.6 & $2.333333 c$ \\
\hline $\operatorname{SEM}( \pm)$ & 1.65 & 1.63 & 0.06 & 0.5 & 0.04 & 0.2 \\
\hline LSD (0.05) & 11.8 & 10.4 & 0.325 & 3.65 & 0.28 & 1.1 \\
\hline CV (\%) & 5.96 & 17.6 & 10.2 & 21.9 & 22.9 & 20.1 \\
\hline F-test & NS & $*$ & $* *$ & NS & NS & $*$ \\
\hline
\end{tabular}

Note: Means with the same letter are non-significant at $\mathrm{p}=0.05$ by DMRT, SEM: Standard error of mean, LSD: Least significant difference, CV: Coefficient of variation, NS: Non-significant, ${ }^{*}: 5 \%$ level of significance, ${ }^{* *}: 1 \%$ level of significance.

Table 10. Effect of different fertilizer on performance of okra at 70 DAS.

\begin{tabular}{lccc}
\hline \multirow{2}{*}{ Treatments } & \multicolumn{2}{c}{ 70 DAS } & Number of fruits \\
\cline { 2 - 4 } & Number of buds & Number of open flowers & 2.333333 \\
Sesame cake & $15.033333^{\mathrm{a}}$ & 1.6000000 & 2.466667 \\
Poultry manure & $14.40000^{\mathrm{ab}}$ & 1.2000000 & 2.533333 \\
Synthetic fertilizers & $12.200000^{\mathrm{abc}}$ & 0.9333333 & 2.600000 \\
Goat manure & $11.266667^{\mathrm{bc}}$ & 1.1333333 & 2.266667 \\
Mustard cake & $10.933333^{\mathrm{bc}}$ & 1.1333333 & 2.933333 \\
Vermicompost & $10.133333^{\mathrm{c}}$ & 1.1333333 & 2.266667 \\
Control & $9.466667^{\mathrm{c}}$ & 1.0666667 & 0.12 \\
SEM( \pm (0) & 0.74 & 0.08 & 1.1 \\
LSD (0.05) & 3.43 & 0.575 & 24.8 \\
CV (\%) & 16.2 & 27.1 & $\mathrm{NS}$ \\
F-test & $*$ & $\mathrm{NS}$ & $\mathrm{N}$ \\
\hline
\end{tabular}

Note: Means with the same letter are non-significant at $p=0.05$ by DMRT, SEM: Standard error of mean, LSD: Least significant difference, CV: Coefficient of variation, NS: Non-significant, ${ }^{*}: 5 \%$ level of significance. 
The effect of different fertilizer on the yield was found significant at $1 \%$ probability level. Poultry manure producing $20 \mathrm{mt} / \mathrm{ha}$ was found superior (Table 11). It was followed by vermicompost, goat manure, sesame cake, mustard cake, synthetic fertilizers and untreated control. The effects of different fertilizers on different growth parameters like plant diameter, height, number of leaves and yield was found highest in Poultry manure which corroborates with the findings of (Fagwalawa and Yahaya, 2016). The increase in yield of Okra was due to the easy Solubilization effect and high nitrogenous contents of Okra and it agrees with the findings of (Sanwal et al., 2007) in turmeric and (Premsekhar and Rajashree, 2009) in Okra in which they respond organic manure improves the physical properties of soil. The BC ratio was highest in poultry manure followed by goat manure, sesame cake, synthetic fertilizers, vermicompost, untreated control and mustard cake (Table 13). Vermicompost produced the comparatively superior yield but due to the high cost of the manure, the $B C$ ratio seems to be quite low. In case of synthetic fertilizers, though they produced the fewer yields but due to the low cost of the fertilizers, they have quite superior $B C$ ratio.

From the above experiment, Poultry manure was found to be superior among all the seven treatments on different growth parameters like plant diameter, height, number of leaves and yield except the number of buds at 70DAS (on significant cases) which corroborates with the findings of Fagwalawa and Yahaya (2016). Benefit Cost ratio was highest in poultry manure followed by goat manure, sesame cake, synthetic fertilizers, vermicompost, untreated control and mustard cake. Hence, it can be concluded that usage of Poultry manure improves the performance of growth parameters and finally increases the yield (200 qt./ha) and have high BC ratio (1.77). It has been estimated that the application of poultry manure releases the nutrient easily and improves the nutrient status of the soil by easy solubilization effect and high-water holding capacity of it. Thus, increases the overall growth parameters of the crop. This result agrees with the findings of Sanwal et al. (2007); Premsekhar and Rajashree (2009).

Table 11. Effects of different fertilizers on yield.

\begin{tabular}{ll}
\hline Treatments & Average Yield (mt/ha) \\
\hline Poultry manure & $20.00000^{\mathrm{a}}$ \\
Vermicompost & $17.386667^{\mathrm{ab}}$ \\
Goat manure & $16.728889^{\mathrm{ab}}$ \\
Sesame cake & $16.622222^{\mathrm{ab}}$ \\
Mustard cake & $14.644444^{\mathrm{bc}}$ \\
Synthetic fertilizers & $12.506667^{\mathrm{cd}}$ \\
Control & $9.613333^{\mathrm{d}}$ \\
SEM( \pm$)$ & 0.82 \\
LSD (0.05) & 3.86 \\
CV $(\%)$ & 14.1 \\
F-test & $* *$ \\
\hline
\end{tabular}

Note: $\mathrm{mt}=$ metric ton $(1000 \mathrm{~kg})$, Means with the same letter are non-significant at $\mathrm{p}=0.05$ by DMRT, SEM: Standard error of mean, LSD: Least significant difference, CV: Coefficient of variation, ${ }^{* *}: 1 \%$ level of significance.

Table 12. Estimation of common-cost of various components.

\begin{tabular}{ll}
\hline Particulars & Amount (NRs/ha) \\
\hline Rental value of land & 105,000 \\
Field preparation & 6,000 \\
Seed cost & 23,089 \\
Irrigation cost & 66,000 \\
Manuring (Labour) & 1,800 \\
Weeding & 18,000 \\
Harvesting & 24,000 \\
Total & 243,889 \\
\hline
\end{tabular}

Note: NRs: Nepalese Rupees. 
Table 13. Estimation of cost of different components.

\begin{tabular}{|c|c|c|c|c|c|c|}
\hline \multirow{2}{*}{ Treatments } & \multirow[t]{2}{*}{$\begin{array}{c}\text { Common cost } \\
\text { (NRs/ha) }\end{array}$} & \multicolumn{4}{|c|}{ Cost of fertilizers (NRs/ha) } & \multirow[t]{2}{*}{$\begin{array}{l}\text { Total cost } \\
\text { (NRs/ha) }\end{array}$} \\
\hline & & $\begin{array}{c}\text { Respective } \\
\text { manures }\end{array}$ & $\begin{array}{l}\text { Single Super } \\
\text { Phosphate }\end{array}$ & $\begin{array}{c}\text { Diammonium } \\
\text { phosphate }\end{array}$ & $\begin{array}{c}\text { Muriate of } \\
\text { potash }\end{array}$ & \\
\hline Poultry manure & 243,889 & 83,333 & 11,812 & - & - & 339,034 \\
\hline Vermicompost & 243,889 & 153,160 & 4,390 & - & - & 401,979 \\
\hline Goat manure & 243,889 & 33,333 & 12,750 & - & - & 289,972 \\
\hline Sesame cake & 243,889 & 75,611 & 13,102 & - & 2670 & 335,272 \\
\hline Mustard cake & 243,889 & 132,733 & 113,90 & - & - & 388,012 \\
\hline Synthetic fertilizers & 243,889 & 5632 & - & 17,608 & 6,000 & 273,129 \\
\hline Control & 243,889 & - & - & - & - & 243,889 \\
\hline
\end{tabular}

Note: NRs: Nepalese Rupees, ha: hectare.

Table 14. Benefit-Cost (BC) ratio of the cultivation of okra.

\begin{tabular}{llll}
\hline Treatments & $\begin{array}{l}\text { Benefit } \\
\text { (NRs/ha) }\end{array}$ & $\begin{array}{l}\text { Total cost } \\
\text { (NRs/ha) }\end{array}$ & BC ratio \\
\hline Poultry manure & 600,000 & 339,034 & 1.77 \\
Vermicompost & 521,580 & 401,979 & 1.30 \\
Goat manure & 501,840 & 289,972 & 1.73 \\
Sesame cake & 498,660 & 335,272 & 1.49 \\
Mustard cake & 439,320 & 388,012 & 1.13 \\
Synthetic fertilizers & 375,180 & 273,129 & 1.37 \\
Control & 288,390 & 243,889 & 1.18 \\
\hline
\end{tabular}

Note: Selling Price estimated at NRs. 30 per kg okra, BC: Benefit-cost, NRS: Nepalese Rupees, ha: hectare.

\section{Conclusion}

From this study, it was concluded that, highest benefit cost ratio of 1.77 was found in the case of poultry manure with the productivity of $20 \mathrm{Mt} / \mathrm{ha}$. This study identifies the poultry manure is superior in almost all the vegetative and reproductive parameters of the plant. Hence, use of poultry manure was observed beneficial in terms of economical and production perspectives. Further multi trial and multi-location research should be carried out to suggest the most suitable dose of poultry manure to obtain the maximum profit. Vermicompost, producing the significant superior yield and have less $\mathrm{BC}$ ratio, so suitable research should be carried out to prepare cost efficient vermicompost to obtain the better results.

\section{ACKNOWLEDGEMENT}

We acknowledge the Department of Horticulture of Agriculture and Forestry University (AFU) for their continuous support and coordination during the entire research duration.

Open Access: This is an open access article published under the terms and conditions of Creative Commons AttributionNonCommercial 4.0 International License which permits noncommercial use, distribution, and reproduction in any medium, provided the original author(s) if the sources are credited.

\section{REFERENCES}

Ajari, O., Tsado, L., Oladiran, J. and Salako, E. (2003). Plant height and fruit yield of okra as affected by field application of fertilizer and organic matter. The Nigerian Agricultural Journal , 34: 74 - 80.

Akande, M.O., Oluwatoyinbo, F.I., Adediran, J.A. and Buari, K. (2003). Soil amend- ments affect the release of $\mathrm{P}$ from rock phosphate and the development and yield of Okra. Journal of Vegetable Crop Production, 9(2): 3-9, https://doi.org/10.1300/J068v09n02_02

Aniefiok, I.A. (2013). Effects of Poultry Manure and Plant Spacing on the Growth and Yield of Waterleaf (Talinum fructicosum L. Juss). Journal of Agronomy, 12 (3): 146-152

Awodun, M.A. (2007). Effect of Goat Manure and Urea Fertilizer on soil, Growth and Yield of Okra. International Journal of Agricultural Research, 2(7): 632-636, https://doi.org/10.3923/ijar.2007.632.636

Ayeni, L.S. (2011). Integrated Plant nutrition management : A panacea for sustainable crop production in Nigeria. International Journal of Soil Sciences, 1: 19-24.

Buob, T. (2008). Fertilizing the Organic Garden. University of New Hampshire Cooperative Extension, pp. 1-4.

Fagwalawa, L.D. and Yahaya, S.M. (2016). Effect organic manure on the growth and Yield of Okra. Imperial Journal of Agriculture, 2(3): 130-133.

Farinde, A.J., Owolarafe, O.I., and Ogungbemi, O.I. (2007). An overview of production, processing, marketing and Utilisation of Okra in Egbedore Local Government Area of Osun State, Nigeria. Agricultural Engineering International : the CIGR Ejournal. 9: 1-10.

Frederick, E.N. (2015). Management of root-knot nematode (Meloidogyne spp.) on okra (Abelmoschus esculuntus (L.) Moench) with aqueous sesame seed extract. International Journal of Agronomy and Agricultural Research, 6: 24-31.

Garg, S. and Bahl, G.S. (2008). Phosphorus availability to maize as influenced by organic manures and fertilizer $\mathrm{P}$ associated phosphatase activity in soils. Bioresource Technology, 99(13): 5773-5777, https://doi.org/10.1016/j.biortech.2007.10.063

Kumar, V., Chopra, A.K., Srivastava, S., Singh, J. and Thakur, R.K. (2017). Irrigating okra with secondary treated municipal wastewater: Observations regarding plant growth and soil characteristics. International Journal of Phytoremediation, 19(5): 490-499, https://doi.org/10.1080/15226514.2016.1244169

Kumar, R. (2019). The Impact of chemical fertilizers on our environment and ecosystem. Research Trends in Environmental Sciences, pp. 69-86.

Maurya, R.P., Bailey, J.A. and Chandler, J.S. (2013). Impact of plant spacing and picking interval on the growth, fruit quality and yield of okra (Abelmoschus esculentus L. Moench). American Journal of Agriculture and Forestry, 1(4): 48-54.

Premsekhar, M. and Rajashree, V. (2009). Influence of organic manure on growth, yield and quality of okra. American Eurasian Journal of Sustainable Agriculture, 3(1): 6-8. 
Sanwal, S., Lakminarayana, K., Yadav, R., Rai, N., Yadav, D. and Mousumi, B. (2007). Effect of organic manures on soil fertility, growth, physiology, yield and quality ofturmeric. Indian Journal of Horticulture, 64(4): 444 - 449.

Sinha, R.H. (2009). Earthworms vermicompost: A Powerful Crop Nutrient over the Conventional Compost and Protective Soil Conditioner against the Destructive Chemical Fertilizers for Food Safety and Security. American-Eurasian Journal of Agricultural and Environmental Sciences, 1: 1-10.
Sumbul, R.R. (2015). Oil-Cake Amendments: Useful Tools for the Management of Phytonematodes. Asian Journal of Plant, 3: 91-111.

Titiloye, E.O., Lucas, E.O. and Agbola, A.A. (1985). Evaluation of fertilizer value of organic waste materials in South Western Nigeria. Biological Agriculture Horticulture, 7: 25-27.

Ware, G.W. and Collum, J.M. (1980). Producing Vegetable Crops. The Interstate Printers and Publishers, Danville VA, X: 607. 